\title{
Agricultural mechanization, a key to food security in developing countries: strategy formulating for Iran
}

\author{
Mohammad Emami ${ }^{1}$ (D, Morteza Almassi ${ }^{1 *}$, Hossein Bakhoda ${ }^{1}$ and Issa kalantari ${ }^{2}$
}

\begin{abstract}
Background: Mechanization is a multi-dimensional concept and widely used in agriculture. There is, however, a major difference between the application of mechanization in developed and developing countries The developing countries tend to design their own strategies in food security given the challenges they face in all aspects of their economy including feeding a growing population, reducing poverty, protecting the environment, managing the effects of climate change and fighting malnutrition all which may further contribute to a reduction in economic growth and political instability. The goal of the strategies, with the help of appropriate technologies, is to lead to a sustainable agricultural development and, ultimately, food security. The policy making in each country should be based on its own conditions. This article uses Iran as an example of a developing country and considers the country's specific climate as well as political and economic conditions to present development-oriented policies for achieving sustainable food security based on agricultural mechanization that may be adaptable to other developing countries. The main objective of this paper is to identify and provide guidelines to the current and future challenges of Iran's food security, and it argues that for any strategy to succeed in producing a sustainable agricultural production, it will need a proper analysis and a formulation of an appropriate mechanization plan.
\end{abstract}

Methods: To achieve the objective of a self-sustaining agricultural mechanization strategy, a SWOT analysis technique was used to identify the strengths, weaknesses, opportunities and threats and help us provide a framework by which policies can be defined. The framework includes internal and external factors that affect the development of agricultural mechanization and seek to provide ideas for agricultural development with the help of mechanization. These factors were then prioritized using the Hierarchical Analysis Method, and based on the obtained results, the final strategies were extracted and prioritized by the Technique for Order of Preference by Similarity to Ideal Solution (TOPSIS), a multi-criteria decision analysis method.

Results and conclusion: According to the results, weaknesses and threats were the most important factors. Environmental threats, especially water shortages, economic problems as well as availability of the mechanization fleet and compatibility of the equipment within the country's agricultural system were identified as the most important factors affecting the agricultural development. In order to achieve sustainable food security, with regards to the identified factors the necessary recommendations and Governmental-support policies in the agricultural sector were presented: 1. reforming the country's planting pattern according to the climatic conditions considering the relative advantage of agricultural production, 2 . modernizing the mechanization fleet; 3 . investing in research and development of agriculture and modern knowledge; the production and import of agricultural machinery and modern technologies according to their suitability with the country's conditions and future needs of the country; strengthening of the supply chain and maintenance services.

\footnotetext{
${ }^{*}$ Correspondence: morteza.almassi@gmail.com

1 Department of Agricultural Mechanization, Science and Research

Branch, Islamic Azad University, Tehran, Iran

Full list of author information is available at the end of the article
}

C The Author(s) 2018. This article is distributed under the terms of the Creative Commons Attribution 4.0 International License (http://creativecommons.org/licenses/by/4.0/), which permits unrestricted use, distribution, and reproduction in any medium, provided you give appropriate credit to the original author(s) and the source, provide a link to the Creative Commons license, and indicate if changes were made. The Creative Commons Public Domain Dedication waiver (http://creativecommons.org/ publicdomain/zero/1.0/) applies to the data made available in this article, unless otherwise stated. 
Keywords: Food security, Agricultural mechanization, Policy making, Strategy formulating, Developing countries, Iran

\section{Background}

Agricultural mechanization today has a very broad meaning. This broad meaning includes production, distribution and utilization of a variety of tools, machinery and equipment for the development of agricultural land, planting, harvesting and primary processing [3, 15, 19, 25]. Today, the debate on development of agricultural mechanization turns into the debate on improving of agricultural techniques as well as helping them improve the sustainability of the entire agricultural system [19]. Evidence suggests that mechanization has a major impact on demand and supply of farm labor, agricultural profitability, and a change in rural landscape [24] and can be defined as an economic application of engineering technology to increase the labor efficiency and productivity. The United Nations Food and Agriculture Organization (FAO) and the United Nations Industrial Development Organization (UNIDO) concluded that the goal of agricultural mechanization is to reduce labor. Increasing productivity by updating executive operations in order to gain more power, increasing the level of cultivated land, moving toward industrialization and strengthening the market for rural economic growth and ultimately improving the livelihoods of farmers are the goals of mechanization $[11,12,15]$.

In the pre-industrial stage in Western countries, one of the strategies to increase agricultural production was mechanization. At this stage, the agricultural sector used high-capacity machinery for crop operations that were suitable for large land and replacement of labor. History shows that agricultural mechanization has led to rapid industrialization in the western hemisphere. More recently in the twenty-first century, many Asian countries have embraced this western thinking and implemented mechanization policies in accordance with their own particular circumstances [5]. Mechanization technology changes with industrial growth in the country and economic and social progress of the farmers. While the loss of interest in agriculture by land owners and the lack of access to agricultural labor force for farm operations are among the most important social and economic issues in highly industrialized countries, increasing the area of cultivation and increasing labor productivity are the requirements of mechanization in developing countries. Therefore, mechanization technology requires dynamic and regional conditions [27]. For example, mechanization in countries such as the USA and Canada has dramatically changed from the perspective of cultivating based on the time of initial deployment, but in many developing countries, agriculture still has a strong dependence on labor [24]. To this end, developing countries, on their path to achieving food security, need to design their own strategies for agriculture.

Achieving food security in an environmentally sustainable way is one of our greatest challenges [4]. To this end, policies must be selected that, with the help of appropriate technology, will lead to sustainable development of agricultural production in developing countries and ultimately will lead to sustainable food security.

\section{World food security and developing countries}

In the first half of the twenty-first century, the world faces numerous challenges to feed the growing population, reduce poverty, protect the environment and face climate change. These challenges can sustain hunger and malnutrition, reduce economic growth-lead to political instability and irreversible damage to the environment and human survival $[19,28]$. The latest estimate of hunger is 795 million people [14], and as the world's population grows to over 9 billion people by 2050, it is anticipated that the need to meet the ever-increasing demand for more food is urgent and necessary [26]. As some sources predict, global food demand for that year will be twice as much as it is now [16]. As productivity growth is not enough in many developing countries to respond to rising demand, imported food in these countries are expected to increase dramatically [23]. Today, despite considerable investment in development, food insecurity is widespread throughout East and West Africa [22]. In Sub-Saharan Africa, we have witnessed an increase in imports over the last forties, where food products have not been responsive to growing populations [13]. Also, the Middle East, as one of the developing regions of the world, must cope with many of the unintended and unforeseen consequences of modernization. Increasing birth rate and rapidly growing population in the area, paying more attention to urbanization among policymakers and neglecting rural development, becuase of increasing rural-to-city migration, unbridled expansion of governments, etc., are among these consequences. The development of agriculture in this area has not been sufficient to provide a satisfactory level of national supply for achieving food security and the availability of domestic food resources [1]. On the other hand, food security in many countries of the region, such as Iraq, is heavily influenced by the oil-based economy, over three decades of war and its policies [31]. From Iran in the east to Morocco in the west, the Middle East has 
witnessed a deepening dependence on food imports, and this trend continues at a high rate. However, the Arab Spring showed that availability of food at affordable prices is still a prominent feature of many economic, social and political perspectives in the Middle East [1]. On the other hand, the World Food Crisis (2006-2006) has led many countries to reassess their dependence on imports for a significant portion of their food consumption [9]. These countries imposed trade restrictions and moved toward self-sufficiency. Due to the high prices and fluctuations of the market during this period, it was obvious that these countries would be concerned about the excessive dependence on the world food markets and take on such policies.

But on the contrary, some policymakers believe that food security will be achieved by considering comparative advantage in agricultural production, reducing trade restrictions and strengthening and development of international food trade [7]. This article, based on evidence from Iran, provides policies for achieving sustainable food security in developing countries. These development policies are based on agricultural mechanization.

Iran is the second largest country in the Middle East, both in terms of size and population. A quarter of Iran's population lives in rural areas (Fig. 1). And $21.2 \%$ of the total working population of the country are employed in the agricultural sector [10]. Despite having oil revenues, agriculture plays an important role in the economy of Iran. Despite the declining share of agricultural sector in gross domestic product (GDP), this figure is estimated at about 12\% in 2017 (Fig. 2).

Agricultural development has long been at the heart of Iran's food and agricultural policies. But statistics show the deep dependence of food security on imports. For

\section{Rural and urban population} 2017

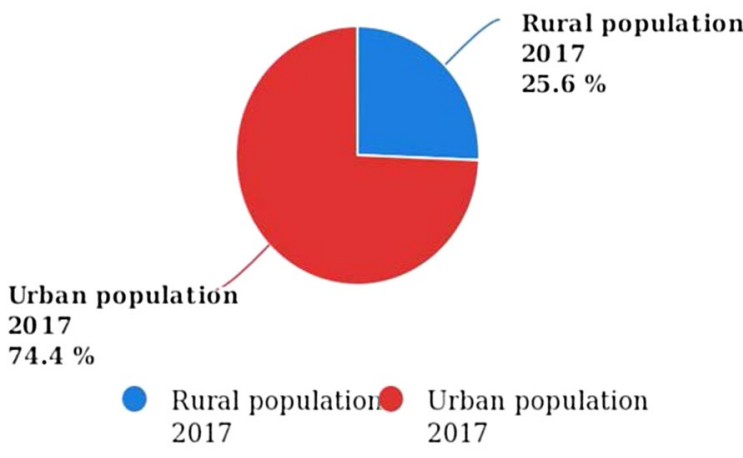

Fig. 1 Rural and urban population of Iran example, the dependence ratio for grain imports in Iran is $28.7 \%$ in 2014, and the country's food imports are still high (Fig. 3). The exploitation of water resources in Iran, with more than $70 \%$ above the global average, is inefficient [17]. Meanwhile, 74\% of Iran's land, about 120 million hectares, is inappropriate for agriculture [18]. It is expected that in the years to come, there will not be enough water even for such a small amount of agricultural land. These conditions along with its political and international issues and its foreign policies, make the future of agriculture and food security in Iran more difficult and challenging. Under these circumstances, Iran must identify current challenges and focus on the future of food and agriculture.

\section{Agricultural mechanization strategy and food security}

Considering the necessity of identifying and responding to the current and future challenges of food security in order to lead, collaborate and design the related strategies [30], this paper, by examining the current state of Iran and identifying challenges and threats, seeks to provide strategies to promote the role of agricultural mechanization in agricultural development as a solution to the achievement of food security.

Any attempt to increase agricultural production without considering a proper mechanization strategy would never have a positive outcome [20]. A sustainable agricultural mechanization strategy is a planning strategy that contributes to the goal of sustainable agriculture, and at the same time accepts food self-sufficiency and generates economic and inclusive growth as well as social benefits [19].

Increasing food production along with maintaining natural resources is not an easy task. The second green revolution, which in the second half of the last century was able to produce more than twice the amount of food, is currently not in a good position. The growth rate of major cereal yields (wheat, rice and corn) is declining. Increasing food production requires resource-friendly methods, and this will require the development of new mechanization technology [26]. There are many technology options, but there is relatively scarce evidence of supporting decision making in the form of technology [23]. While one of the major constraints on developing and modernizing production in developing countries is the low level of engineering technology in agriculture [12]. Despite its many values and undeniable benefits, which are briefly mentioned above, mechanization is still considered as an input, such as other inputs, like fertilizers, seeds, and chemical protection products and in the most optimistic way, it is one of the combined management tools aimed at maximizing farmers' productivity and profits [8]. Despite the impact of agricultural 


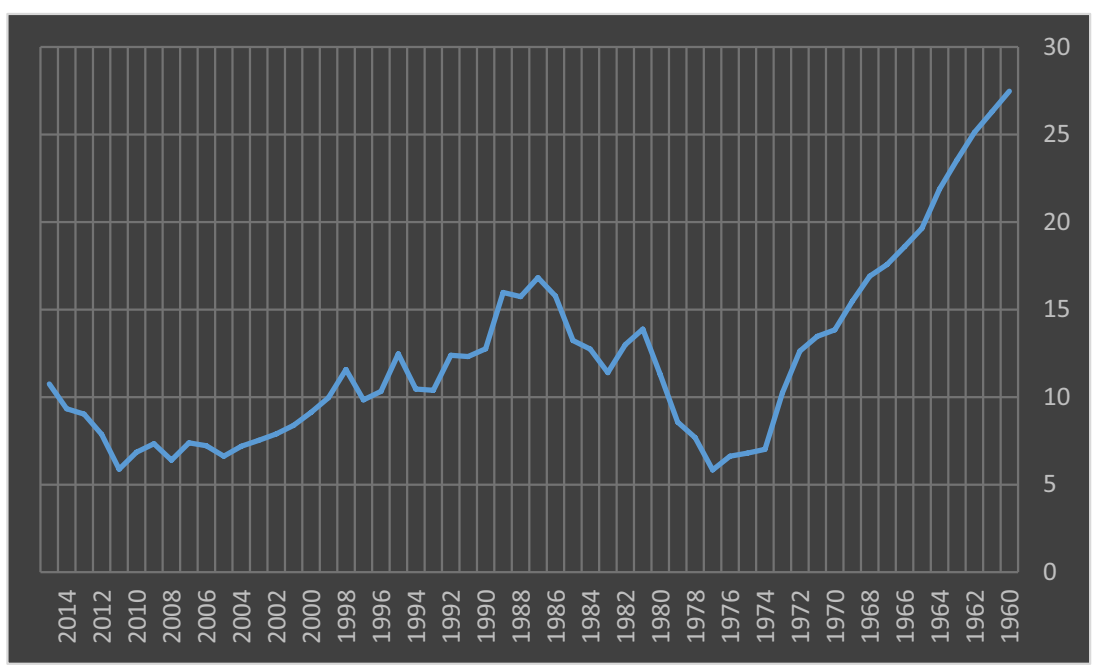

Fig. 2 Agricultural value added. Source: World Bank (OCT 28, 2017)

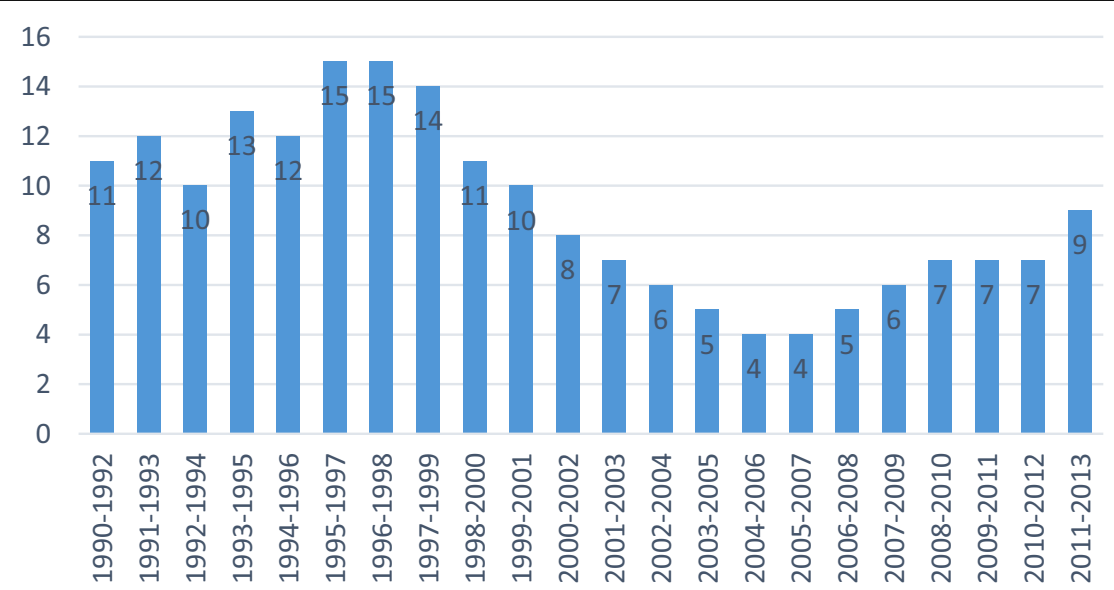

Fig. 3 Value of food imports

mechanization on the agricultural production process, due to the lack of comprehensive research on the extent of the effect of mechanization components on the production and its fields of application, there were always differences of opinion and doubts about the role of mechanization in the agricultural sector. This has prevented the stabilization and improvement in agricultural mechanization in the agricultural sector and even in the sectors of industry and services in developing countries. For example, the FAO report on the state of mechanization in the African countries [12] indicates that most African countries have not taken serious plans for sustainable mechanization, and efforts have failed to reach mechanization issues due to the micro, rather than macro, approaches. Studies show that crop production is more beneficial in areas where agricultural mechanization is provided [15]. According to the research conducted in mechanized agricultural areas, yields were significantly higher than non-mechanized areas. The use of pesticides was also more effective, and the land and fertilizers were used optimally. This is the need of the world today, achieving food security by preserving natural resources for future generations.

\section{Methods}

The purpose of agricultural policy is to develop appropriate and sustainable guidelines for promotion of efficient agricultural practices that guarantee food security, generate employment for citizens, provide raw materials for all agricultural industries, and also to acquire foreign currency. Agriculture can work with other sectors of the economy to achieve faster development, poverty 
reduction and environmental sustainability $[3,6,20]$. This usually requires upgrading of infrastructure and injection of technology to advance production from the early stages of agriculture to mechanical systems through a suitable political framework [3]. Also, economic development studies have focused on the importance of addressing the fundamental constraints on elimination of poverty in general and improvement in the performance of smallholder farmers. Many proven technologies and planting improvement practices have promise to boost agricultural production and reduce poverty in developing countries [21]. Here is where agricultural mechanization plays its role, and therefore developing countries need to design a new strategy based on mechanization. Various activities involved in the formation of a strategy can be divided into three stages: (1) status analysis; (2) strategy development; and (3) strategy approval [12]. All three stages were conducted in this research. The selection of appropriate policies to promote the role of agricultural mechanization in agriculture to achieve food security is the ultimate goal of this research. Policies create the parameters in which development programs are implemented. The strategy determines what resources should be available for development programs and how to identify, mobilize, deploy and maintain these resources for implementation of these programs [20]. On the other hand, mechanization planning requires a quantitative evaluation of the mechanization index and its impact on agricultural production (yield) and economic factors (cost of cultivation, deployment of harmful and mechanical force and economic advantage) [27]. In order to achieve this goal, considering strengths, weaknesses, opportunities and threats (SWOT), a matrix was created as a political and analytical framework. The framework includes internal and external factors that influence the development of agricultural mechanization and seeks to provide ideas for agricultural development with the help of agricultural mechanization. These factors were prioritized by AHP hierarchical analysis method. At the next stage, the strategies were extracted according to the obtained results. In the final section, strategies were prioritized by TOPSIS method.

\section{Study design and data collection}

In this research, data were collected from a combination of primary and secondary sources to analyze the role of agricultural mechanization in agricultural development and the achievement of sustainable food security in developing countries. The preliminary data were taken from the Ministry of Agriculture's official statistics, Statistical Centre of Iran, the Agricultural Mechanization Development Center, as well as the Ministry of Commerce of Iran. Secondary data were collected from the stakeholders during the interviews. Experts were selected using the Sampling Snowball method. This technique is a sequential targeted sampling method that can be used in a multi-criteria decision-making process in which the researcher, after identifying the individuals introduced by an expert, asks them to introduce one or more other specialists. These experts included government employees in the areas of planning, implementation, monitoring and evaluation of mechanization, private sector, research and educational institutions, university professors and Ph.D. students in mechanization. Using questionnaires distributed among them, internal factors (strength and weakness) and external factors (opportunities and threats) were identified. In this study, 22 factors were agreed as internal and external factors. By identifying strategies and internal and external factors, comparative questionnaires were designed to compare the factors together. A pairwise comparison was performed by hierarchical analysis method (AHP). A binary comparison was performed based on scale of 1-9. The principles of this comparison scale are shown in Table 1 [29].

\section{Results \\ Identifying internal and external factors}

According to the results obtained and the findings of previous researches of experts, and based on the designed questionnaire, they identified weaknesses, strengths, opportunities and threats (Table 2).

Twenty-two factors were identified as internal and external factors. Disturbances in the form of macroeconomic factors on one hand and environmental constraints on the other especially the water crisis, are among the most important factors identified along with the status of Iran's agricultural mechanization fleet.

\section{Prioritizing the factors}

At this stage of the research, the identified internal and external factors were prioritized by hierarchical analysis method (Table 3).

Based on the findings of this section, the weaknesses were identified as the most effective factor compared to other factors with an importance coefficient of 0.467 . The threats were identified as the next effective factor, with

\section{Table 1 The fundamental scale of AHP}

\begin{tabular}{ll}
\hline Score & Definition \\
\hline 1 & Equal importance \\
3 & Weak importance of one over another \\
5 & Essential or strong importance \\
7 & Very strong and demonstrated \\
9 & Absolute importance \\
$2,4,6,8$ & Intermediate values between adjacent scale values \\
\hline
\end{tabular}


Table 2 The summary of SWOT analysis results of development agricultural mechanization in Iran

\begin{tabular}{|c|c|}
\hline \multicolumn{2}{|l|}{ Internal factors } \\
\hline Weaknesses & Strengths \\
\hline $\begin{array}{l}\text { 1. Lack of proper distribution and the heterogeneous amount of machinery } \\
\text { and technology in the agricultural sector }\end{array}$ & 1. Ability of cultivating strategic products in many parts of the country \\
\hline 2. Disproportion size of agricultural land and existing agricultural machinery & 2. Dependence of the production of these products on energy inputs \\
\hline 3. Use of amortized machines and consequently increased waste & 3. Growing capacity of country mechanization \\
\hline $\begin{array}{l}\text { 4. Lack of correlation between the increase in Indicators of machinery and } \\
\text { the reduction of waste }\end{array}$ & $\begin{array}{l}\text { 4. Significant correlation between mechanization capacity index and } \\
\text { increase in wheat production }\end{array}$ \\
\hline $\begin{array}{l}\text { 5. Gradual growth of the agricultural sector compared to other economic } \\
\text { sectors of the country }\end{array}$ & $\begin{array}{l}\text { 5. Increasing trend and moving toward increasing and improving energy } \\
\text { indicators }\end{array}$ \\
\hline \multicolumn{2}{|l|}{ External factors } \\
\hline Threats & Opportunities \\
\hline 1. High cost of ownership for beneficiaries & 1. Climate diversity \\
\hline 2. High dependence on fossil fuels & 2. Suitable market for exporting to countries of the region \\
\hline 3. High cost of exchanging rate and impact on the economy & 3. Large number of graduates in agriculture \\
\hline 4. Lack of interest in investing in the manufacturing sector & 4. Possibility of modifying seeds and using biotechnology in production \\
\hline $\begin{array}{l}\text { 5. Growing trend in the service sector and the downward trend in manufac- } \\
\text { turing sectors }\end{array}$ & $\begin{array}{l}\text { 5. Major factories of agricultural machinery production in the country } \\
\text { and the history of decades of manufacturing and exporting machinery }\end{array}$ \\
\hline \multicolumn{2}{|l|}{$\begin{array}{l}\text { 6. Expanding urbanization and lack of interest in engaging in agricultural } \\
\text { activities }\end{array}$} \\
\hline 7. Water bankruptcy of the country & \\
\hline
\end{tabular}

Table 3 Pairwise comparison of SWOT factors

\begin{tabular}{llllll}
\hline & Strength & Weakness & Opportunity & Threat & Importance degree of SWOT factors \\
\hline Strength & 1 & 0.333 & 2 & 0.5 & 0.160 \\
Weakness & 3 & 1 & 4 & 2 & 0.467 \\
Opportunity & 0.5 & 0.25 & 1 & 0.333 & 0.095 \\
Threat & 2 & 0.5 & 3 & 1 & 0.277 \\
& & & & & $C l=0.01$ \\
\hline
\end{tabular}

an importance coefficient of 0.277 , and subsequently, the strengths and opportunities were prioritized, respectively, with importance coefficients of 0.160 and 0.095 .

These results indicate that the weaknesses and threats are more important in the current challenges of Iran compared to the strengths and the opportunities, leading Iran to the more defensive or more conservative strategies.

Due to the higher coefficient of importance of weaknesses in comparison to threats, it is necessary to pay more attention to internal factors in the agricultural sector and mechanization of Iran rather than external factors.

\section{Prioritizing the sub-actors}

Prioritizing the sub-factors based on internal and external factors was the next step in this study. At this stage, sub-factors were prioritized in four groups and were compared to other sub-factors (Table 4).

The weaknesses SWOT factor has the most importance among internal and external factors, and the most important sub-factor is the lack of proper distribution and the heterogeneous amount of machinery and technology to the agricultural sector. The importance coefficient of this sub-factor is estimated at 0.427 . This suggests that despite the high agricultural mechanization coefficient in Iran, distribution of machinery in this country has not been done properly. Also, many new technologies in the agricultural sector have not been properly utilized. The second weakness, which earns the second rank, with an importance coefficient of 0.236 , also emphasizes this issue. The disproportion size of agricultural land and existing agricultural machinery is identified as the second most important sub-factor. These sub-factors both 
Table 4 Relative priority of each SWOT sub-factors

\begin{tabular}{|c|c|c|c|c|c|c|c|c|}
\hline$S$ & S1 & S2 & S3 & S4 & S5 & & & Relative priority \\
\hline S1 & 1 & 5 & 2 & 3 & 4 & & & 0.420 \\
\hline S2 & 0.2 & 1 & 0.25 & 0.5 & 0.5 & & & 0.067 \\
\hline S3 & 0.5 & 4 & 1 & 2 & 3 & & & 0.264 \\
\hline \$4 & 0.33 & 2 & 0.5 & 1 & 2 & & & 0.148 \\
\hline \multirow[t]{2}{*}{ S5 } & 0.25 & 2 & 0.33 & 0.5 & 1 & & & 0.099 \\
\hline & & & & & & & & $\mathrm{Cl}=0.01$ \\
\hline W & W1 & W2 & W3 & W4 & W5 & & & \\
\hline W1 & 1 & 2 & 4 & 5 & 3 & & & 0.427 \\
\hline W2 & 0.5 & 1 & 2 & 3 & 2 & & & 0.236 \\
\hline W3 & 0.25 & 0.5 & 1 & 2 & 0.5 & & & 0.109 \\
\hline W4 & 0.2 & 0.33 & 0.5 & 1 & 0.5 & & & 0.072 \\
\hline \multirow[t]{2}{*}{ W5 } & 0.33 & 0.5 & 2 & 2 & 1 & & & 0.153 \\
\hline & & & & & & & & $\mathrm{Cl}=0.01$ \\
\hline $\mathrm{O}$ & 01 & $\mathrm{O} 2$ & $\mathrm{O} 3$ & O4 & O5 & & & \\
\hline 01 & 1 & 4 & 2 & 3 & 0.5 & & & 0.266 \\
\hline $\mathrm{O} 2$ & 0.25 & 1 & 0.33 & 0.5 & 0.166 & & & 0.059 \\
\hline $\mathrm{O} 3$ & 0.5 & 3 & 1 & 2 & 0.5 & & & 0.174 \\
\hline $\mathrm{O} 4$ & 0.33 & 2 & 0.5 & 1 & 0.25 & & & 0.097 \\
\hline \multirow[t]{2}{*}{ O5 } & 2 & 6 & 2 & 4 & 1 & & & 0.401 \\
\hline & & & & & & & & $\mathrm{Cl}=0.01$ \\
\hline T & $\mathrm{T} 1$ & $\mathrm{~T} 2$ & T3 & $\mathrm{T} 4$ & T5 & T6 & $\mathrm{T7}$ & \\
\hline $\mathrm{T} 1$ & 1 & 5 & 2 & 3 & 4 & 3 & 0.5 & 0.232 \\
\hline $\mathrm{T} 2$ & 0.2 & 1 & 0.25 & 0.33 & 0.5 & 0.33 & 0.142 & 0.036 \\
\hline T3 & 0.5 & 4 & 1 & 1 & 3 & 2 & 0.33 & 0.132 \\
\hline $\mathrm{T} 4$ & 0.33 & 3 & 1 & 1 & 3 & 2 & 0.33 & 0.121 \\
\hline T5 & 0.25 & 2 & 0.33 & 0.33 & 1 & 0.5 & 0.166 & 0.0509 \\
\hline T6 & 0.33 & 3 & 0.5 & 0.5 & 2 & 1 & 0.25 & 0.081 \\
\hline \multirow[t]{2}{*}{$\mathrm{T7}$} & 2 & 7 & 3 & 3 & 6 & 4 & 1 & 0.343 \\
\hline & & & & & & & & $\mathrm{Cl}=0.01$ \\
\hline
\end{tabular}

underline the poor distribution of agricultural machinery in Iran, and suggests that the distribution of machinery across the country is not proportionate to the size of Iran's agricultural land. After the land reforms at the time of the former regime in Iran, the division of agricultural land has been one of the issues that policymakers point to as a barrier to Iranian agricultural development. This problem however can be resolved by planning and subsequent distribution of machinery, appropriate to the demand. The gradual growth of the agricultural sector, in comparison with other economic sectors of the country, has been ranked third, with an importance coefficient of 0.153. In recent years, development of the various economic sectors of Iran has not been coordinated. The service sector in Iran has had the highest development rate, and after the agreement on the nuclear program between Iran and the P $5+1$, the oil sector has been well developed. The agricultural sector and the industrial sector did not have significant development and have a small share of gross domestic product. The two following sub-factors are related to the amount of waste, as well as the contribution of mechanization to reducing this amount. Given the role that mechanization plays in different stages of production, it can have an effective contribution to reducing agricultural waste. The statistics in Iran however, indicate low correlation between mechanization and reduction of agricultural waste. The use of amortized machines, lack of scheduled plans and lack of attention to timeliness costs are among the reasons for this low correlation. Statistics show that the amount of agricultural and food waste in Iran is very high. Correct management of agricultural mechanization can play an important role in reducing waste and, consequently, in achieving food security. Threats, after weaknesses, rank second in terms of importance (Table 3). Among the subfactors in this group, water bankruptcy, with an importance coefficient of 0.343 , has the highest rank. Iran has been in crisis for many years and today the crisis has 
exceeded the warning threshold. The continuation of this process is a threat not only to the agriculture of Iran, but also to its civilization. After the water crisis, the High cost of ownership for beneficiaries is in the second place, while the high cost of exchange rates in the economy of Iran is in the third place. These sub-factors both will ultimately lead to a low level of investment in the agricultural sector. This factor, with an importance coefficient of 0.121 , ranks next. Dependence on fossil fuels, urbanization and development of the service sector and declining trend of manufacturing sectors are among the following sub-factors.

The third factor is the Strengths, with an importance coefficient of 0.160 . In terms of importance of the subfactors, the ability of cultivating strategic products in many parts of the country, with an importance coefficient of 0.420 , is ranked first. The growing capacity of the country mechanization is ranked second, and the subfactor of the significant correlation between mechanization capacity index and increase in wheat production is ranked third. The two following sub-factors are related to energy indicators. Increasing trend and moving toward increasing and improving energy indicators, with an importance coefficient of 0.099 , is in the fourth place and the dependence of the production of these products on energy inputs is in the fifth place. The increasing trend of energy indicators on one hand and the dependence of production on these indicators on the other indicate that Iran should maintain the status quo and try to improve these indicators.

In the ranking of opportunities sub-factors in Iran, major factories of agricultural machinery production in the country and the history of decades of manufacturing and exporting machinery, with an importance coefficient of 0.401 , ranked first. The country's climate diversity ranked second. Iran is a country with four seasons throughout the year. This feature provides a decent opportunity for policymakers to have more options to manage the food market in the country. The large number of graduates in agricultural, with an importance coefficient of 0.174 , is the third most important subfactor. The large number of graduates gives Iran the opportunity to make its agriculture more scientific, as an example, Iran can take steps in the field of biotechnology and seed improvement. The possibility of modifying seeds and using biotechnology in production is in the fourth place. This sub-factor is reinforced with the help of the former sub-factor, the large number of experts in Iran. The last sub-factor is the suitable market for exporting to countries of the region, which Iran can plan for it as an appropriate opportunity.

\section{Extracting strategies}

After studying internal and external factors, strengths, weaknesses, opportunities and threats and their ranking, finally, according to the political, economic, social and environmental structure of the country, eight final strategies were proposed by the experts (Table 5 ).

The extracted strategies were prioritized using the TOPSIS method. At first, each of the eight strategies was ranked based on the sub-factors (Table 6) and finally they ranked accordingly (Table 7).

\section{Discussion}

According to Table 7, Injecting proper financial investment into the agricultural sector, with an importance coefficient of 0.194, was ranked first. Despite its prominent role in achievement of food security, Iran's agricultural sector is considered the weakest among the economic sectors. Low development of this sector over the years and lack of interest in investing in it is alarming. As such policymakers should prioritize strategies to strengthen this sector and support it. Earlier, FAO, in a report reviewing the state of agricultural mechanization in African countries [12], presented strategies to achieve lasting effects, such as political will and commitment at the highest possible level, allocating funds to the agricultural sector and providing appropriate loans to small farmers. These proposals were presented by FAO, due to the weakness of the private sector and the lack

\section{Table 5 Suggested strategies}

\begin{tabular}{|c|c|}
\hline Suggested strategies & \\
\hline $\begin{array}{l}\text { 1. Considering the relative advantages of producing and planning for the } \\
\text { development of food and international trade }\end{array}$ & $\begin{array}{l}\text { 5. Producing or importing agricultural machinery and new technologies, } \\
\text { according to their suitability with the conditions of the country, along } \\
\text { with strengthening of the supply chain and maintenance service }\end{array}$ \\
\hline $\begin{array}{l}\text { 2. Energy management, moving toward clean energies and improving } \\
\text { energy indicators }\end{array}$ & $\begin{array}{l}\text { 6. Investing in agricultural research and development and the use of } \\
\text { biotechnology and modern knowledge }\end{array}$ \\
\hline $\begin{array}{l}\text { 3. Modifying consumption patterns by replacing high-yield products in the } \\
\text { household basket }\end{array}$ & $\begin{array}{l}\text { 7. Modifying Iran's cultivation pattern based on the state of the country's } \\
\text { production resources with attention to the state of the country's water } \\
\text { resources }\end{array}$ \\
\hline 4. Injecting proper financial investment to the agricultural sector & 8. Employing graduates directly in the agricultural sector \\
\hline
\end{tabular}




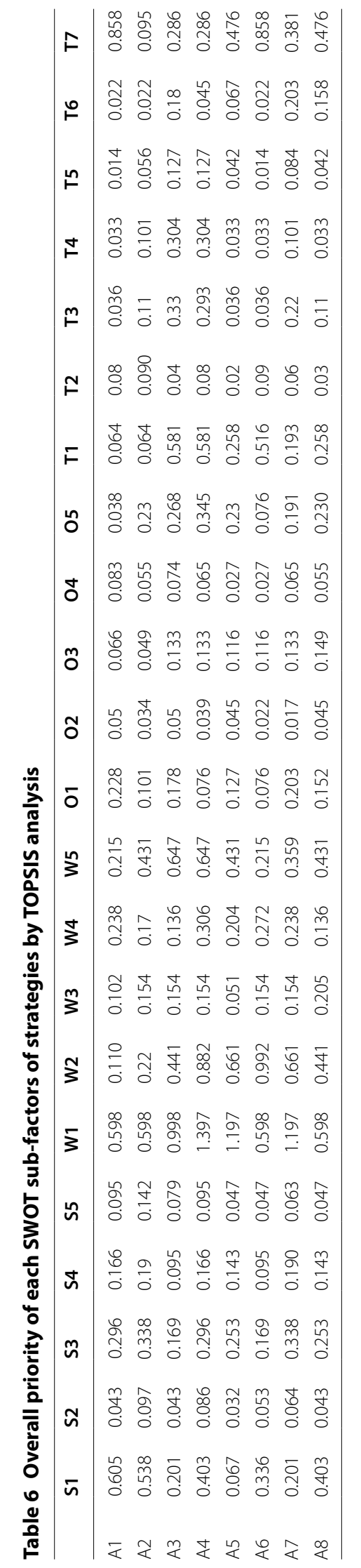


Table 7 Overall priority of each strategy

\begin{tabular}{lll}
\hline Strategy & Overall priority & Ranking result \\
\hline A1 & 0.130 & 4 \\
A2 & 0.076 & 8 \\
A3 & 0.099 & 6 \\
A4 & 0.194 & 1 \\
A5 & 0.136 & 3 \\
A6 & 0.117 & 5 \\
A7 & 0.163 & 2 \\
A8 & 0.081 & 7 \\
\hline
\end{tabular}

of government intervention agricultural investment and commerce, which seems to be in line with the situation in Iran.

Modifying Iran's cultivation pattern based on the state of the country's production resources with attention to the state of the water resources is ranked second with an importance coefficient of 0.163 . The severe water crisis in Iran, or in other words, bankruptcy of water, has put the country in a difficult position. According to this situation, Iran must not only take more water-efficiency measures, but must also reform its cultivation pattern based on the need for water for agricultural products and available water resources. And, if necessary, implement "not to do farming" Project in the required areas.

Producing or importing agricultural machinery and new technologies, according to their suitability with the conditions of the country, along with strengthening of the supply chain and maintenance service is ranked third with an importance coefficient of 0.136 . The need for investment in the supply chain of machinery as a shortterm solution, along with technical training and proper management for businesses and service and maintenance, are among the suggestions of researchers [26]. The use of machines that are unsuitable for the country's condition, on one hand, and the worn-out fleet of agricultural machinery in many parts of the country on the other, makes it necessary to modernize the fleet and to distribute it more appropriately throughout the country, which is possible due to the existence of tractor and combine factories in Iran and their history.

Considering the relative advantages of producing and planning for development of food and international trade is ranked third with an importance coefficient of 0.130 . Food security is one of the responsibilities of the government of each country. One of the most important dimensions of food security is food availability. The government is required to distribute a decent number of calories in the country based on the nutritional needs of its population. This amount of energy will be supplied either through domestic production or through imports. According to this strategy, it is recommended that Iran, to establish this dimension of food security, considers the relative advantages of production as its agenda. If a product or several products have no comparative advantage in production, instead of spending resources for its production, the country should strengthen its international trade by importing the needed products and avoid the problem of this dimension of food security, and at the same time, use its resources appropriately to maximize productivity in production.

The next strategy is investing in agricultural research and development and the use of biotechnology and its new knowledge. This strategy ranked with an importance coefficient of 0.117. Due to the limitation of arable land in Iran, the country must move toward increasing productivity per unit area. New technologies and biotechnology are among the things that make this possible for each country and for this reason, Iran should invest in agricultural research and development. Seed modification, genetic modification, etc., are among the many ways to develop agriculture and achieve sustainable food security. Researchers believe that the development of food security is possible through the development and promotion of technology. These achievements are mainly attributed to increased use of crop improvement methods. These results highlight the role of improved methods for promoting agricultural productivity among small farmers [21]. Researchers are also strategizing with emphasis on technology transfer and planning for the development of agricultural mechanization. It is suggested that the first step is to remove the obstacles that mechanization faces including the fact that small farmers do not have the financial ability to move to mechanized cultivation require government support. The government support at the executive and legislative levels, supporting academic education, providing appropriate technology and services, and moving toward the assembly and production of agricultural machinery are among these proposals [20]. The emphasizing on research and development, the selection and transferring appropriate technologies for the region, optimal use of energy resources, increasing the number of machinery, training, providing loans to farmers, as well as providing tax rebates are among the proposed policies in this area [2]. Iran also can take steps to maximize the productive use of resources using precision farming technology, given the country's water crisis. Modifying consumption pattern by replacing highyield products in the household basket is the sixth ranked strategy that is related to the dimension of food utilization. Modifying this pattern requires long-term cultural and social planning. Dietary habits in Iran are not only rooted in different cultures in this country, but also 
closely related to religious beliefs. To achieve this, various government and community-based organizations, such as the media, social networks and NGOs, can play a significant role. Employing graduates directly in the agricultural sector, with a 0.081 significance factor, is the next strategy. Iran has a large number of agricultural graduates and has a major need for agriculture production based on science and technology, which has been addressed in previous strategies. The government can, with proper planning, use this potential to develop its agricultural sector and move toward reducing unemployment. Energy management, moving toward clean energies and improving energy indicators, is the last strategy with an importance coefficient of 0.076. Considering the abundant oil and gas resources of Iran, there seems to be less interest in moving toward such energies in the country. Most of the country's environmental crises are caused by pollution from fossil fuels.

\section{Conclusions}

In this research, we identified the weaknesses, strengths, threats and opportunities facing Iran's agricultural development to achieve the main objective of the research. In the next step, these factors were prioritized, with weaknesses and threats having the highest score in prioritizing by hierarchical analysis method. Environmental threats especially water bankruptcy; unfavorable conditions of Iran's arable land; economic problems; lack of proper development in agricultural sector in comparison with other economic sectors; exhaustion and disproportion of the mechanization fleet with conditions of the country were considered as the most important problems facing the country's agricultural development. To achieve sustainable food security, with regards to the identified factors and considering the opportunities and strengths of Iran, with the future in mind, the necessary strategies were presented in this paper. Strategies are classified in the category of defensive policies with respect to the importance coefficients of weaknesses and threats compared to the other factors. Government support policies in the agricultural sector; reforming the country's planting pattern according to the climatic conditions; taking into account the relative advantage of agricultural production as well as modernizing Iran's mechanization fleet, investing in agricultural research and development and moving toward modern knowledge; given the large number of agricultural graduates in Iran; the production or import of agricultural machinery and modern technologies, according to their suitability with the country's conditions and future needs; along with strengthening of the supply chain and maintenance services were among these strategies that were prioritized by the TOPSIS method.

\section{Authors' contributions}

The authors collaboratively designed the study, performed the literature review and analysis, and wrote and edited the manuscript. All authors read and approved the final manuscript.

\section{Author details}

${ }^{1}$ Department of Agricultural Mechanization, Science and Research Branch, Islamic Azad University, Tehran, Iran. ${ }^{2}$ Department of Environment, Tehran, Iran.

\section{Acknowledgements \\ Not applicable.}

\section{Competing interests}

The authors declare that they have no conflict of interest to the publication of this article. There are no patents or copyrights relevant to this work. There are no relationships or activities to disclose that could be perceived to have influence the submitted work.

\section{Availability of data and materials}

The datasets generated and analyzed during the current study are available from the corresponding author on request.

\section{Consent for publication}

The authors hereby consents that the Publisher publishes the Work in Agriculture \& Food Security.

\section{Ethics approval and consent to participate}

This study does not involve any human, animal or plant subjects, and materials. The authors have read and agreed to its content and that the manuscript conforms to the journal's policies and this project has been considered by the Ethics Committee and ethical approval is granted.

\section{Funding}

The authors received no financial support for the research and/or authorship of this article. No financial relationships exist with any entities that could be perceived to influence the submitted work.

\section{Publisher's Note}

Springer Nature remains neutral with regard to jurisdictional claims in published maps and institutional affiliations.

Received: 4 February 2018 Accepted: 28 February 2018

Published online: 23 March 2018

\section{References}

1. Abi Said M, Hakimi A, Babar Z, Bush R, Chaaban J, Crist JT, Mundy M. Food security and food sovereignty in the middle east. Washington, DC: Georgetown University; 2012.

2. Ahmad T. Agricultural mechanization research and development in the Islamic Republic of Pakistan. Beijing: United Nations Centre for Sustainable Agricultural Mechanization; 2015.

3. Akinbamowo RO. A review of government policy on agricultural mechanization in Nigeria. J Agric Ext Rural Dev. 2013;5(8):146-53.

4. Alemu MH, Olsen SB, Vedel SE, Kinyuru JN, Pambo KO. Can insects increase food security in developing countries? An analysis of Kenyan consumer preferences and demand for cricket flour buns. Food Secur. 2017:9(3):471-84

5. Amongo RC, Larona ML. Agricultural mechanization policies in the Philippines. Beijing: United Nations Centre for Sustainable Agricultural Mechanization; 2015

6. Byerlee D, Janvry AD, Sadoule E, Townsend R, Klytchnikova I. Agricultral for development. Washington, DC: The World Bank; 2008.

7. Clapp J. Food self-sufficiency: making sense of it, and when it makes sense. Food Policy Issue. 2017;66:88-96.

8. Clarke L. Strategise for agricultral mechanization development. Rome: Agricultural Support System Division, FAO; 2000. 
9. FAO. The state of food insecurity in the world (economic crises-impacts and lessons learned). Rome: FAO; 2009.

10. FAO. FAO statistical pocketbook. Rome: FAO; 2015.

11. FAO and UNIDO. Agricultural mechanization in Africa ... Time for action: planning investment for enhanced agricultural productivity. Rome: FAO; 2008.

12. Fonteh MF. Agricultural mechanization in Mali and Ghana: strategies, experiences and lessons for sustained impacts. Rome: FAO; 2010.

13. Graaf JD, Kessler A, Nibbering JW. Agriculture and food security in selected countries in Sub-Saharan Africa: diversity in trends and opportunities. Food Secur Issue. 2011:3:195-213.

14. Grebmer KV, Bernstein J, Prasai N, Amin S, Yohannes Y, Towey O, Nabarro D. Global hunger index getting to zero hunger. Washington, DC: IFRIP; 2016

15. Haruna IM, Junior JA. Mechanization practice: a tool for agricultural development in nigeria: a case study of Ifelodun local government area of Kwara State. Int J Basic Appl Sci. 2013;2(3):98-106.

16. Joffre OM, Castine SA, Philips MJ, Senaratna Sellamuttu S, Chandrabalan D, Cohen P. Increasing productivity and improving livelihoods in aquatic agricultural systems: a review of interventions. Food Secur. 2017;9(1):39-60.

17. Lehane S. The Iranian water crisis. Nedlands: Future Directions International; 2014.

18. Mesgaran MB, Madani K, Hashemi H, Azadi P. Iran's land suitability for agriculture. Sci Rep. 2017;7:7670

19. Mrema G, Soni P, Rolle RS. A regional strategy for sustainable agricultural mechanization: sustainable mechanization across agri-food chains in Asia and the Pacific region. Bangkok: FAO; 2014.

20. Negrete JC. Strategies for technology transfer of agricultural mechanization in Mexico. Int Res J Adv Agric. 2015;1 (1):1-11.
21. Pan Y, Smith SC, Sulaiman M. Agricultural extension and technology adoption for food security: evidence from Uganda. New York: Institute for International Economic Policy; 2015.

22. Ritzema RS, Frelat R, Douxchamps $S$, Silvestri S, Rufino MC, Herrero M, van Wijk MT. Is production intensification likely to make farm households food-adequate? A simple food availability analysis across smallholder farming systems from East and West Africa. Food Secur. 2017;9(1):115-31.

23. Rosegrant MW, Koo J, Cenacchi N, Ringler C, Robertson R, Fisher M, Sabbagh P. Food security in a world of natural resource scarcity, the role of agricultural technologies. Washington, DC: IFPRl; 2014.

24. Schmitz A, Moss CB. Mechanized agriculture: machine adoption, farm size, and labor displacement. AgBioForum. 2015;18(3):278-96.

25. Simalenga T. Entrepreneurship in mechanized agriculture technologyoriented operations. Agric Mech J (AMA). 2000;31(3):61-88.

26. Sims B, Kienzle J. Mechanization of conservation agriculture for smallholders: issues and options for sustainable intensification. Environments. 2015;2015(2):139-66.

27. Singh G. Estimation of a mechanisation index and its impact on production and economic factors a case study in India. Biosys Eng. 2006;93(1):99-106.

28. Sundaram KJ, Dawe D, Haen DH, Stamoulis K, Wiebe K. The state of food insecurity in the world 2012: economic growth is necessary but not sufficient to accelerate reduction of hunger and malnutrition. Rome: FAO; 2012.

29. Triantaphyllou E. Multi-criteria decision making methods: a comparative study. Dordrecht: Springer; 2000.

30. Walport M. Global food security strategic plan 2011-2016 updated November 2013. Global Food Security; 2013.

31. Woertz E. Food security in Iraq: results from quantitative and qualitative surveys. Food Secur. 2017;9(3):511-22.

\section{Submit your next manuscript to BioMed Central and we will help you at every step:}

- We accept pre-submission inquiries

- Our selector tool helps you to find the most relevant journal

- We provide round the clock customer support

- Convenient online submission

- Thorough peer review

- Inclusion in PubMed and all major indexing services

- Maximum visibility for your research

Submit your manuscript at www.biomedcentral.com/submit
O) BioMed Central 